\title{
LA PROHIBICIÓN DE LA MATERNIDAD SUBROGADA, ¿RESULTA INCOHERENTE CON NUESTRO ORDEN PÚBLICO INTERNACIONAL?
}

\author{
Ezequiel Caride \\ Abogado, Doctorando en Ciencias Jurídicas \\ Profesor de Posgrado e Investigador \\ Universidad Católica Argentina, Buenos Aires, Argentina \\ Contacto: ezequielcaride22@gmail.com
}

Recibido: 12 de julio de 2021

Aprobado: 9 de agosto de 2021

Para citar este artículo:

Caride, E. (2021). "La prohibición de la maternidad subrogada, ¿resulta incoherente con nuestro orden público internacional?".

Prudentia Iuris, N. 92, pp. 185-220

DOI: https://doi.org/10.46553/prudentia.92.2021.pp.185-220

Resumen: El trabajo revisa una postura favorable a la maternidad subrogada, que sur-
giría de una interpretación particular del Derecho Internacional Privado en materia de
reconocimiento de filiación extranjera en el Código Civil y Comercial de la Nación.
Para ello, se analizan las bases culturales y la determinación jurídica de la maternidad
en nuestro país, la caracterización de la maternidad subrogada y los dilemas que apare-
cen en la figura en su proyección global; se profundiza en la noción del orden público y
en los criterios que fundan el orden público internacional, sus matices y la doctrina de
los últimos pronunciamientos judiciales internacionales; sobre esas bases, se concluye
que nuestro orden jurídico, más allá de las modulaciones propias de la materia inter- 
nacional, rechaza los contratos de gestación por sustitución y las situaciones abusivas asociadas a ellos.

Palabras clave: Maternidad subrogada, Orden público internacional, Técnicas de reproducción humana asistida, Derecho a la identidad, Interés superior del niño, Dignidad de la mujer. 


\title{
The prohibition of surrogacy, is it incompatible with our international public order?
}

\begin{abstract}
This paper reviews a position favorable to surrogacy, which would arise from a particular interpretation of Private International Law regarding the recognition of foreign affiliation in the Civil and Commercial Code of the Nation. For this, the cultural bases and the legal determination of motherhood in our country, the characterization of surrogacy and the dilemmas that appear in the figure in its global projection are analyzed; It delves into the notion of public order and the criteria that found international public order, its nuances and the doctrine of the latest international judicial pronouncements; on these bases, it is concluded that our legal order, beyond the modulations of international matters, rejects surrogacy contracts and abusive situations associated with them.
\end{abstract}

Keywords: Surrogacy, International public order, Assisted human reproduction techniques, Right to identity, Best interests of the child, Dignity of women.

\section{Il divieto di maternità surrogata, È incompatibile con il nostro ordine pubblico internazionale?}

Sommario: Il presente contributo esamina una posizione favorevole alla maternità surrogata, che deriverebbe da una particolare interpretazione del Diritto Internazionale Privato in merito al riconoscimento dell'affiliazione straniera nel Codice Civile e Commerciale della Nazione. Per questo vengono analizzate le basi culturali e la determinazione giuridica della maternità nel nostro Paese, la caratterizzazione della maternità surrogata e i dilemmi che compaiono nella figura nella sua proiezione globale; Approfondisce la nozione di ordine pubblico ei criteri che fondano l'ordine pubblico internazionale, le sue sfumature e la dottrina degli ultimi pronunciamenti giudiziari internazionali; Su queste basi si conclude che il nostro ordinamento giuridico, al di là delle modulazioni delle questioni internazionali, rifiuta i contratti di maternità surrogata e le situazioni abusive ad essi associati. 
Parole chiave: Maternità surrogata, Ordine pubblico internazionale, Tecniche di riproduzione umana assistita, Diritto all'identità, Superiore interesse del bambino, Dignità delle donne.

\section{Introducción ${ }^{1}$}

En este trabajo se tratará la siguiente cuestión: si resulta incoherente con nuestro orden público internacional considerar que el orden jurídico interno prohíbe o rechaza la maternidad subrogada como técnica de reproducción humana asistida con efectos de emplazamiento filial.

Para ello, se expondrá el planteo realizado en un voto en disidencia, de una reciente resolución judicial ${ }^{2}$; para luego delimitar el concepto, implicancias y proyección global de la maternidad subrogada; a continuación ver la configuración y los alcances de nuestro orden público; y seguir con la caracterización y los matices del orden público internacional y jurisprudencia internacional en la materia.

Por último, se presentará una conclusión sobre la cuestión tratada, como consecuencia de las consideraciones precedentes.

\section{Planteo de la cuestión}

El argumento surge, en las consideraciones de un voto disidente, para resolver un caso judicial promovido por dos varones que reclamaban una pretensión de filiación contra la mujer gestante, solicitando que se la desplace de su estado de madre, y se ordene la rectificación de la partida de nacimiento, a consecuencia de que la niña nació por intermedio de técnicas de reproducción humana asistida y que la demandada actuó como gestante, sin voluntad de ser madre ${ }^{3}$.

1 Trabajo perteneciente al Proyecto Ius 2019/2021, "Discrecionalidad judicial en materia filiatoria, con especial referencia a los casos de maternidad subrogada", Facultad de Derecho - Universidad Católica Argentina, Buenos Aires, Argentina.

El autor agradece los valiosos comentarios de Analía Pastore sobre el borrador de este trabajo y las sugerencias de Débora Ranieri y Nicolás Lafferriere para su publicación.

2 Cámara Nacional en lo Civil (CNCiv.), sala K, causa "F., R. R. y otro c/ G. P., M. A. s/ impugnación de filiación”, del 28 de octubre de 2020, con voto de la mayoría integrada por los Dres. Osvaldo O. Álvarez y Oscar J. Ameal que rechazó la demanda, y el voto en disidencia de la Dra. Silvia Patricia Bermejo.

3 Ver comentarios favorables a la disidencia de Berterreix, M. L. "Comentario a un fallo desalentador sobre las técnicas de reproducción humana asistida"; y Quaini, F. "La gestación por sustitución, un obstáculo cultural más que jurídico o técnico"; ambos en La Ley 21-12- 
La magistrada consideró que el legislador argentino no prohibió o descartó la figura de la gestación por sustitución y que tal postura se coordina con lo previsto en el artículo 2634 del Código Civil y Comercial de la Nación.

Analizó que la normativa citada prevé que todo emplazamiento filial constituido de acuerdo con el Derecho extranjero debe ser reconocido por la República de conformidad con los principios de nuestro orden público, especialmente aquellos que imponen darle prioridad al interés superior del niño.

Además, señaló que el segundo párrafo del artículo 2634 del Código Civil y Comercial de la Nación establece que los preceptos que regulan las normas sobre filiación por técnicas de reproducción humana asistida integran el orden público y deben ser ponderadas por la autoridad a los efectos del reconocimiento de estado o inscripción de personas nacidas a través de estas técnicas.

De todo ello, la camarista coligió que la gestación por otro no conculca el orden público, porque de lo contrario no se podría haber incorporado un artículo como el 2634, rematando que la coherencia de un mismo sistema jurídico no puede permitir una autocontradicción o un doble estándar de antijuridicidad.

Concluyó que no se podría admitir que la gestación sustituta realizada en el extranjero se anote en nuestro país, como lo establece el artículo citado, si resulta un reconocimiento de un derecho contrario a nuestro ordenamiento jurídico.

\section{Maternidad subrogada}

\section{1) Concepto}

De manera preliminar, conviene realizar una salvedad de índole lingüística; aun cuando adelanto que el término maternidad subrogada es el más adecuado para definir la problemática, se utilizará en forma indistinta con otras expresiones, como gestación por sustitución y gestación por otro, ya que ahondar en la terminología excede los fines de la presente obra. Ello, sin negar que carece de inocencia cómo se denomina la práctica procreativa analizada ${ }^{4}$.

\footnotetext{
2020; y comentario crítico de Sambrizzi, E. A. "Correcto rechazo a un reclamo de maternidad subrogada”. El Derecho 22-2-2021 y 23-2-2021.

4 López Quintas, A. (1987). “La manipulación del hombre a través del lenguaje”, disponible en https://www.racmyp.es/docs/anales/A64-15.pdf.
} 
Como dice el cuentista, "omitir siempre una palabra, recurrir a metáforas ineptas y a perífrasis evidentes, es quizá el modo más enfático de indicarla"5.

La definición de maternidad, según el diccionario de la RAE, resulta "estado o cualidad de madre", y madre se define, en su primera acepción, como "hembra que ha parido", y en su segundo significado, como "hembra con respecto de su hijo o hijos", asociando la voz maternidad de modo inescindible al hecho del parto, al estado de embarazo antecedente de la mujer y a la criatura que nace como consecuencia del alumbramiento ${ }^{6}$.

Sumado a ello, desde una mirada cultural, la natalidad se la relaciona con la acción del nacimiento, que surge como la principal facultad humana para interferir con el curso inexorable de la vida hacia su ruina y destrucción y con la capacidad peculiar de deshacer los procesos históricos predestinados, cíclicos y fatales, que "encontró tal vez su más gloriosa y sucinta expresión en las pocas palabras que en los evangelios anuncian la gran alegría 'Os ha nacido hoy un Salvador"' 7 .

Además, en la tradición cristiana, que se reconoce en nuestro ordenamiento jurídico como componente de la formación cultural y estirpe de la Nación ${ }^{8}$, ante las lágrimas de una mujer por la muerte de su hijo $(\operatorname{Lc} 7,13)$, en el texto inspirado se revela la intensidad de la conmoción divina por la necesidad humana, con una compasión de profundis, mediante un verbo griego que indica las vísceras o el útero materno ${ }^{9}$.

Por otra parte, en la cultura de los pueblos incaicos se evidenciaba que "la madre propia criaba a su hijo; no se permitía darlo a criar, por gran señora que fuese, sino era por enfermedad [...]. Ésta era la común costumbre que las indias del Perú tenían en el parir y criar sus hijos, hecha ya naturaleza, sin distinción de ricas a pobres ni de nobles a plebeyas"10.

Asimismo, en las leyes de Indias, se amparaba a la madre y su vientre, al prohibir que se empleara como nodriza a las aborígenes de los pueblos americanos, proclamando así el valor intrínseco del ser humano, "que nin-

5 Borges, J. L. (2017). "El jardín de senderos que se bifurcan”. En Borges esencial. Real Academia Española y Asociación de Academias de la lengua española. Barcelona. Alfaguara, 73 .

6 Real Academia Española (2006). Diccionario esencial de la lengua española. Madrid. Espasa Calpe, 916 y 950.

7 Arendt, H. (2016). La condición humana. $1^{\mathrm{a}}$ edición mejorada. Buenos Aires. Paidós, 266.

8 Corte Suprema de Justicia de la Nación (CSJN), Fallos: 210:58 "Taylor" (1948).

9 Francisco (2016). El nombre de Dios es Misericordia. Una conversación con Andrea

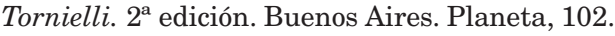

10 Inca Garcilaso de la Vega (1996). Comentarios reales. 6 a edición. Buenos Aires. Plus Ultra, 249-250. 
guna india que tenga hijo vivo pueda venir a criar hijo de español, especialmente de su encomendero"11.

En ese sentido, también surge el vientre materno como punto de partida primigenio de todo vínculo por naturaleza de la filiación, tanto en el Derecho histórico ${ }^{12}$ como en la legislación vigente ${ }^{13}$, siguiendo así el aforismo romano de sapiencia inmemorial partus sequitur ventrem (el parto sigue al vientre), y determinando la normativa aplicable que la maternidad se establece con la sola prueba del nacimiento y la identidad del nacido ${ }^{14}$.

Igualmente, la relación materno filial con origen en las técnicas de reproducción humana asistida, según los artículos 562 y 588 del Código Civil y Comercial de la Nación, se determina por el parto y, sumado a ello, la falta de vínculo genético no puede invocarse para impugnar la maternidad; por consiguiente, en estos casos también el punto de partida de la filiación es el vientre de la madre ${ }^{15}$.

En síntesis, en nuestro ordenamiento civil vigente, y en la dinámica cultural que lo precedió y lo sustenta, solamente en la relación filial adoptiva se configura un vínculo legal que independiza el vínculo jurídico de la maternidad con el estado de embarazo y parto de la mujer ${ }^{16}$.

La denominada maternidad subrogada se daría cuando una mujer acepta gestar y dar a luz un niño para entregarlo después del nacimiento a otro/s (varones y/o mujeres), que se convertirán en sus progenitores legales, dándose las siguientes clases de gestación por otro: $1^{a}$ ) a través de la fecundación natural con el padre; $2^{\mathrm{a}}$ ) mediante inseminación artificial del esperma de un varón de la pareja interesada o de un donante en un óvulo suyo; o $3^{\text {a) }}$ por la implantación de un embrión fecundado in vitro, que se originó en gametos de los comitentes y/o de donantes.

Solamente en los dos primeros casos, la madre gestante también es la madre genética del embrión, y en los dos últimos tipos suele intermediar una agencia que fija los márgenes y contenidos de los acuerdos de subrogación.

11 Citado en Palacios, A. L. (1954), La justicia social. Buenos Aires. Claridad, 235.

12 Seoane, M. I. (1990), "Crianza y adopción en el derecho argentino precodificado". Revista de Historia del Derecho, $\mathrm{N}^{\circ}$ 18. Buenos Aires. Instituto de Investigaciones de Historia del Derecho, 355-438.

13 Artículo 242 del Código Civil (t.o. Ley No 24.540) y artículo 565 del Código Civil y Comercial de la Nación.

14 Perrino, J. O.; Basset, Ú. C. [Directora de la actualización y ampliación] (2017). Derecho de Familia. Tomo II, 2482-2485 y Tomo III. $3^{\text {a }}$ edición. Buenos Aires, Abeledo Perrot, 1577 1608.

15 Sambrizzi, E. A. (2016). La Filiación en el Código Civil y Comercial. $1^{\text {a }}$ edición. Buenos Aires. La Ley, 147-149.

16 Cfr. artículos 558, 562, 565, 588 y 594 del Código Civil y Comercial de la Nación. 
En algunos casos concretos promovidos en sede judicial, se hizo lugar a pretensiones vinculadas a la práctica de la maternidad subrogada ${ }^{17}$, aun cuando se puede compartir análisis críticos de los precedentes judiciales, por sus excesos hermenéuticos y voluntarismos, que desvirtúan la regulación de la técnicas de reproducción humana asistida y eluden las garantías judiciales del régimen de filiación adoptiva ${ }^{18}$.

En verdad, surge como una elaboración jurisprudencial con significativos repartos arbitrarios de interpretación de las normas, que exaltan anteproyectos legislativos, mutan normas claras y precisas y minimizan datos sociológicos y la voluntad del legislador, para direccionar la interpretación progresiva hacia una convalidación oficial de convicciones particulares y movimientos de opinión, que carecen de consenso, base antropológica y fuerza normativa ${ }^{19}$.

Repárese que la discrecionalidad judicial se encuentra limitada a la posibilidad de aplicar reglas, principios y estándares normativos del ordenamiento jurídico en casos concretos que pueden tener varias respuestas jurídicas igualmente válidas, perspectiva que exige garantías de objetividad y de concreción equitativa, y que no permite las valoraciones subjetivas del juzgador o las decisiones que estimen únicamente sus propios criterios o intereses $^{20}$.

17 CNCiv., sala H, causa "S. T., V. s/ inscripción de nacimiento", del 15-3-2018 (voto mayoritario de los Dres. Kiper y Fajre), La Ley 2018-E-106; CNCiv., sala I, causa "S., M. D. y otros c/ A., S. S. s/ filiación", del 28-8-2020, La Ley Online; JNCiv. No 86, causa "N. N. o D. G., M. B. M. s/ inscripción de nacimiento", del 18-6-2013, La Ley 2013-D-195; JNCiv. No 8, causa "B., B. M. y otro c/ G., Y. A. s/ impugnación de filiación", del 20-9-2016, DFyP 2017-243; y JNCiv. N $^{\circ}$ 87, causa "O. F., G. A. y otro s/ autorización", del 3-4-2019, RDF 2019-VI-53, entre otros.

18 Marrama, S. E. (2018). "Análisis de un fallo sobre maternidad subrogada a la luz de la doctrina de la arbitrariedad de sentencia". Revista República y Derecho, Volumen III. Disponible en https://repositorio.uca.edu.ar; Gómez, J. L., "Cuestiones de la identidad y del emplazamiento filiatorio de un niño nacido por gestación por sustitución". Revista Derecho de Familia y de las Personas 2019-79; Ales Uría, M. "La maternidad deconstruida: gestación por sustitución con ovodonación". Revista Derecho de Familia y de las Personas 2017-243; y Lafferriére, Jorge Nicolás. "Maternidad subrogada. Límites y dilemas de las tecnologías reproductivas". La Ley 2016-A-1203.

19 Sagüés, N. P., "La 'convención viviente' en la opinión consultiva 24/2017 de la Corte Interamericana de Derechos Humanos". La Ley 2018-C-159.

20 Etcheverry, J. B. (2017). "Rule of law y la discrecionalidad judicial: compatibilidad y recíproca limitación". Revista Derecho del Estudio No 36, 3-21; Etcheverry, J. B. "Causas y naturaleza de la discrecionalidad judicial en la interpretación y aplicación del derecho". Jurisprudencia Argentina 27-7-2011; Sesin, D. J. (2020). "Discrecionalidad. Ponderación. Proporcionalidad”. La Ley, suplemento Constitucional No 7, 1-4; y Oyhanarte, J. "El caso 'Bonfante'. La autolimitación de los jueces”. El Derecho 57-805. 


\section{2) Implicancias}

Cabe destacar que las técnicas de reproducción humana asistida, que surgieron en apariencia como un recurso para superar la esterilidad o infertilidad de las parejas heterosexuales, se convirtieron a posteriori en una manera alternativa de reproducción humana, desvinculada del precedente acto sexual idóneo, que abarca per se también a parejas homosexuales femeninas y mujeres solas; y mediante la práctica de la maternidad subrogada se incluye en la mencionada desvinculación de las condiciones biológicas de la reproducción humana, a los varones solos o en pareja homosexual ${ }^{21}$.

Por esa fragmentación corporal de las mujeres se habilitaría un mercado donde se puede conseguir descendencia sin sexualidad, negándose valor de identidad, sentido y relevancia subjetiva al cuerpo de las mujeres y su constitución reproductiva, y haciendo invisible los riesgos propios del embarazo, parto y posparto, y los procedimientos y vigilancia médicos que afectan la salud, intimidad y el porvenir de la mujer al solo efecto de obtener el producto deseado 22 .

La perspectiva de la liberación de ataduras biológicas, que se invoca en su defensa, en la práctica puede significar el dominio de unos pocos sobre el resto, un poder sobre el hombre de los sistemas planificadores, vinculados en último término a la eugenesia y sus condicionamientos. La llamada conquista del hombre y sus deseos sobre la naturaleza termina en la conversión de los hombres en títeres de otros y en su abolición como ser humano ${ }^{23}$.

Como decía un pensador a mediados del siglo XX, "Se trata de saber si la técnica dispondrá de los cuerpos y las almas de los hombres del futuro, si decidirá no sólo sobre su vida o su muerte, sino de las circunstancias de su vida, como el técnico de la cría de conejos, dispone de los conejos de su conejera" 24 .

Se altera, de esta forma, la relación materno y paterno filial, pasando los hijos a ser aceptados de modo condicional, una vez superadas las exigencias de calidad que deben cumplir para tener derecho a nacer ${ }^{25}$. Así, se entra en una pendiente dramática de darwinismo social, presiones económicas y

21 Bellver Capella, V. (2015). “Nuevas tecnologías? Viejas explotaciones. El caso de la maternidad subrogada internacional”. Revista de Filosofía $\mathrm{N}^{\circ} 11$. Valencia, España, 28-30.

22 Nuño Gómez, L. (2016). "Una nueva cláusula del Contrato Sexual: vientres de alquiler”. Isegoría. Revista de Filosofía Moral y Política No $55,686$.

23 Lewis, C. S. (2000). La abolición del hombre. Santiago de Chile. Andrés Bello, 55-80.

24 Bernanos, G. (1989). La libertad, ¿para qué? $1^{a}$ edición. Madrid. Encuentro, 75.

25 Andorno, R. "La selección embrionaria en la fecundación 'in vitro': el desafío de la nueva eugenesia". Revista de Derecho de Familia y de las Personas 2010-229. 
ética relativista de la dignidad humana, que en su acontecer histórico reveló crueldad, opresión, luto y vejaciones ${ }^{26}$.

Sumado a ello, como sustrato de las pautas instrumentalistas de las técnicas de reproducción asistida se puede encontrar un fuerte vínculo con la medicina enfocada a satisfacer deseos de los individuos, la inclinación social hacia el control de todas las esferas de la vida, la confianza privilegiada en las intervenciones médicas o tecnocracia, y la incapacidad o falta de tolerancia para asumir sentimientos negativos o una realidad familiar vulnerable ${ }^{27}$.

Ello puede reconocerse en la postura actual que valora el dominio despótico sobre la naturaleza, tomándola como materia prima, totalmente dúctil y desprovista de un fin propio, para quedar disponible para cualquier objetivo independiente de su bien. Con los daños ecológicos y el sometimiento progresivo de la naturaleza, se puede constatar la conversión del hombre mismo, como ser natural, en un ser dependiente de ese proceso manipulador ${ }^{28}$.

Una concepción de la naturaleza que la comprende de manera puramente funcional no puede crear puentes hacia la ética y el Derecho, ni capta que nuestro orbe no es solamente un material para usar sin sentido, sino que tiene en sí mismo dignidad y que debemos seguir sus indicaciones. En otras palabras, en nuestra relación con la realidad y con el hombre en particular, se debe escuchar atentamente lo dado, para volver a la profundidad de sus exigencias y a la amplitud de sus miras ${ }^{29}$.

La maternidad subrogada resulta una figura que se puede constatar desde los orígenes de la humanidad, en un contexto de esclavitud o sujeción jurídica especial (v. gr., en la tradición bíblica la concepción de Ismael [Gn $16,1-2])$ y se caracteriza por la disociación de la maternidad y descarte jurídico de la parturienta.

En ese sentido, los efectos irreversibles sobre la gestante se parecen a los regímenes musulmanes de filiación, donde sus características llevan a ignorar las peticiones del propio hijo y la madre en la dicotomía radical

26 O’Mathúna, D. P. (2006). "La dignidad humana en la era nazi, implicaciones para la bioética contemporánea”. The Center for Bioethics \& Human Dignity, disponible en https:// cbhd.org/node/2131.

27 Schotmans, P.; Hansen, B.; Veulemans, S. "Un bebé como terapia. Consideraciones criticas referidas al diagnóstico preimplantatorio para la donación de células madre”. Jurisprudencia Argentina 2007-IV-997.

28 Spaemann, R. (2004). Ensayos filosóficos. Artículos "Naturaleza" y "La actualidad del derecho natural". Madrid. Cristiandad, 23-45 y 67-87.

29 Ratzinger, J., Benedicto XVI (2018). Liberar la libertad. Capítulo VIII, "Afirmar el derecho y combatir contra la injusticia. Discurso en el Bundestag, Alemania, del 22 de septiembre de 2011". Madrid. BAC, 141-149. 
filiación o no filiación, que se determina por la voluntad exclusiva del varón, mediante la presunción de filiación matrimonial o por el cauce del reconocimiento paterno, y ninguna otra persona o autoridad pueden sustituirlo para determinar la filiación ${ }^{30}$.

Lo dicho implica que, sin generalizar sobre el panorama económico de la gestante y los comitentes, el contrato de maternidad por encargo no sea el pacto más apropiado para tener en consideración cuando se piensa en un proceso de contratación entre iguales, pues es un acuerdo en el que una parte siempre es una mujer, mientras que ese factor sexual es variable respecto de los comitentes ${ }^{31}$.

Lo que distingue a la maternidad por encargo, el quid de la práctica de subrogación es la exigencia de una madre ausente.

Se requiere que la mujer que arriesgó su vida y salud para traer al mundo al hijo, que lo lleva en sus entrañas todo el tiempo, que sufrió los cambios hormonales, se expuso a la diabetes gestacional, la preeclampsia, la cesárea y a la esterilidad, amplió su vientre, sus pechos cambiaron para su función alimentaria en el período de lactancia y el ombligo del niño marca para siempre esa unión vital de cuerpos, desaparezca después del parto ${ }^{32}$.

No se cuestiona el vínculo biológico con el padre que paga por el hijo deseado, lo que se rechaza es la maternidad de la gestante, que se considera que sólo brinda un servicio, como el de guardería o niñera.

La conformación de la práctica de la maternidad subrogada aportaría un nuevo modo de docetismo, que vacía las palabras con sentido propio, pierde su peso la encarnación de la palabra maternidad, quedan diluidos los sufrimientos e inconvenientes corporales de la mujer, y se afirma una dimensión purista, aséptica, de belleza artificial y valores evanescentes, que se convierte en espejo de las ideas dominantes y que desfigura la realidad humana y su horizonte teleológico ${ }^{33}$.

Como decían los antiguos, "No es la que llaman madre la que engendra al hijo, sino que es sólo la nodriza del embrión recién sembrado. Engendra el que fecunda, mientras que ella sólo conserva el brote -sin que por ello dejen de ser extraños entre sí-, con tal de que no se lo malogren los dioses. Voy

30 Scotti, L. B. (2014). "La 'maternidad subrogada' en la legislación y jurisprudencia argentinas". Revista digital enletra.com $\mathrm{N}^{\circ} 1,50-51$.

31 Álvarez de Toledo Quintana, L. (2014). "El futuro de la maternidad subrogada en España: entre el fraude a la ley y el correctivo de orden público internacional". Cuadernos de Derecho Transnacional, Vol. 6, $\mathrm{N}^{\circ} 2,12$.

32 Ekman, K. E. (2017). El ser y la mercancía. Prostitución, vientres de alquiler y disociación. Barcelona. Bellaterra, 194.

33 Bergoglio, Jorge Mario. "Algunas reflexiones sobre el Ejercicio de la Justicia hoy”. El Derecho 209-1096. 
a darte una prueba de este aserto. Puede haber padre sin que haya madre. Cerca hay un ejemplo: la hija de Zeus [Atenea]. No se crió en las tinieblas de un vientre, pero es un retoño cual ninguna diosa podría parir"34.

La gestación por otro se diferencia de la noción de las técnicas de reproducción humana asistida con gametos de terceros, en la no fungibilidad de la gestante y su participación activa, riesgosa y duradera en el proceso reproductivo ${ }^{35}$; sucesos que la emparentan a la entrega directa del hijo y la guarda de hecho, que resultan figuras resistidas por nuestro ordenamiento jurídico, por los abusos, arbitrariedades y tráfico que encubren ${ }^{36}$.

A tal fin, obsérvese que las irregularidades de una convención privada de guarda, donde aparecía la cosificación del niño, la desigualdad de recursos de los contratantes y elementos que indicarían la existencia de una contraprestación económica, agravados por la prórroga de tiempo de un vínculo viciado desde su origen por la ilegitimidad y el engaño, más allá de las apariencias delictuales que ostentaba, se determinó que carecía de valor jurídico alguno ${ }^{37}$.

Además, en la maternidad subrogada hay una concepción meramente veterinaria de la mujer, que abandona su dignidad personal y menosprecia a la gestante que pone la integridad de su cuerpo para la anidación del embrión, durante todo el tiempo que dura el embarazo y en el parto, y, por ende, habilita la posibilidad de su fragmentación física, anímica y espiritual, situación que la diferencia del donante de gametos que en un acto separa de su cuerpo un producto ${ }^{38}$.

Por otra parte, la técnica de la gestación sustitutiva, desde el ángulo del niño, afecta su identidad y la posibilidad de conocer sus orígenes, sufre el desgarro de la separación de la madre que lo gestó y el impacto psicológico y social al conocer las circunstancias particulares en que fue concebido, y, por último, nadie se ocupa de los requisitos necesarios de idoneidad de los comitentes, que se exigen en los procedimientos judiciales de adopción ${ }^{39}$.

Lamentablemente, las técnicas de reproducción humana asistida, en las que se pretende inscribir a la práctica de la maternidad subrogada, pre-

34 Esquilo (2000). Las Euménides. Madrid. Gredos, 253.

35 Ales Uría, M. La maternidad deconstruida... Ob. cit., 2017-243.

36 Álvarez, A. (2012). "La adopción". Disponible en la biblioteca digital de la UCA, https://repositorio.uca.edu.ar.

37 Juzgado de Familia No 2, San Martín, provincia de Buenos Aires, causa "M. A. M. y otro s/ guarda de personas", del 28-7-2015, La Ley Online.

38 Ales Uría, M. (2017). "Límites a la disposición sobre el propio cuerpo a partir de un concepto de Dignidad Humana fundante”. La Ley 2017-B-888.

39 Garibo Peyró, A. P. (2017). "El interés superior del menor en los supuestos de maternidad subrogada”. Cuadernos de Bioética XXVIII, $2^{\circ}$. Madrid, España. Asociación Española de Bioética y Ética Médica, 245-259. 
sentan una lógica cosificante de las personas por nacer, ubicando a los embriones como cosas, sin resguardo de su dignidad y sustantividad humana y permitiendo a la "voluntad procreacional" de los adultos, tomar decisiones potestativas sobre su subsistencia, condiciones de vida y emplazamiento filial $^{40}$.

Sobre esa base, se está afectando la summa divisio iuris desde sus orígenes remotos, que distingue entre las personas y las cosas, al tratar al niño, en la práctica de la maternidad subrogada, como un objeto de derecho, una cosa debida en virtud de un contrato, el producto final deseado de los comitentes, que autoriza a la madre a la abdicación de su cualidad de madre y a deshacerse de sus responsabilidades parentales consecuentes ${ }^{41}$.

Mediante el alquiler de vientres se transforma la maternidad en un servicio, cuyo producto final es un hijo valuado en términos monetarios, provocando ello un mercantilismo del hijo y un tráfico de niños, ligado al tangible riesgo de que el niño deje de ser querido y sea abandonado cuando no satisfaga las expectativas y los deseos de los comitentes ${ }^{42}$.

\section{3) Proyección global}

En ese sentido, ¿cuál es el escenario de la maternidad subrogada a nivel internacional?

Para situar el problema a nivel global, debe valorarse la discriminación existente entre naciones ricas o subdesarrolladas, donde los países en vías de desarrollo establecen regulaciones laxas de reconocimiento de validez de los contratos comerciales de gestación por otro, y dentro de las sociedades, en personas integradas y outsiders, al visibilizar las intenciones y la voluntad de los comitentes e ignorar los desequilibrios y abusos en contra de las mujeres embarazadas.

Se reconoce internacionalmente que la maternidad subrogada resulta un negocio global, que, con dispar regulación en las distintas naciones, se permiten acuerdos entre personas domiciliadas en países diferentes, aun

40 Cámara Nacional en lo Civil (CNCiv.), sala G, causa "R. G. A. y otro s/ autorización", del 9-4-2021, La Ley 10-6-2021.

41 Montero, E. (2015). "La maternidad de alquiler frente a la summa divisio iuris entre las personas y las cosas". Revista Persona y Derecho, $\mathrm{N}^{\circ} 72,223-236$.

42 Pastore, A. G. (2018). "Maternidad subrogada: Análisis jurídico de una problemática actual". Conferencia pronunciada en el Instituto de Bioética de la Academia Nacional de Ciencias Morales y Políticas. Buenos Aires. Disponible en https://repositorio.uca.edu.ar. 
de los lugares más distantes, dando lugar así al denominado turismo reproductivo ${ }^{43}$.

A partir de ahí, se puede encontrar la circunstancia paradójica de que en el Reino Unido se legalizó desde 1985 la subrogación altruista y es el país que contrata mayor número, en toda Europa, de mujeres extranjeras para alquiler de sus úteros, con las condiciones establecidas en las regulaciones de los países donde residen las gestantes, que resultan foros favorables al negocio y a sus efectos económicos y familiares en los comitentes.

Siendo ello así, surge como trasfondo la finalidad validadora de las regulaciones de la maternidad subrogada altruista del comercio internacional, llamado turismo reproductivo, que opera en países permeables a las agencias intermediarias, en condiciones de trata de las mujeres gestantes, cosificación de niños, y con la lógica contractual de la búsqueda de la mejor relación calidad-precio del producto ${ }^{44}$.

Máxime cuando verificar la falta de retribución a la gestante resulta una circunstancia de imposible corroboración, cuando inclusive se acepta que por estos acuerdos se obtengan compensaciones y pagos por gastos médicos, legales o por las pérdidas ocasionadas por la maternidad subrogada ${ }^{45}$.

Aún más, se puede ver esa situación de desamparo de las mujeres gestantes en las regulaciones estaduales de Estados Unidos que permiten los contratos comerciales de maternidad subrogada, donde renuncian a la privacidad y confidencialidad entre el médico y el paciente, a la capacidad de tomar decisiones médicas y a su integridad física, y caen en un mercado de carácter predatorio por motivos de estado de necesidad, que socavan su consentimiento informado ${ }^{46}$.

Lo mismo pasa, a partir de la mirada global indicada, con el fundamento de la autodeterminación y autonomía de la gestante, que silencia su instrumentalización y los beneficios económicos de las agencias intermediarias, y que deja de lado la realidad latinoamericana con mayoritarios sectores sociales con necesidades básicas insatisfechas.

Por lo que, mediante la invocación de la liberación de la gestante, se esconde la verdadera situación de explotación y coerción sobre la mujer en

43 Scotti, L. B. (2014). “La 'maternidad subrogada'...”. Ob. cit., 48.

44 Albert, M. (2017). "La explotación reproductiva de mujeres y el mito de la subrogación altruista: una mirada global al fenómeno de la gestación por sustitución”. Cuadernos de Bioética XXVIII, $2^{\circ}$. Madrid, España. Asociación Española de Bioética y Ética Médica, 177-197.

45 Famá, M. V. "El orden público internacional argentino ante la filiación por técnicas de reproducción humana asistida: normativa vigente y solución proyectada". Jurisprudencia Argentina del 19-12-2012, 3.

46 Lahl, J. (2018). "Embarazos contratados expuestos: los contratos de maternidad subrogada no protegen a las madres sustitutas y sus hijos". Disponible en https://centrodebioetica.org. 
la práctica de la maternidad subrogada, ya que la técnica genera mayores inequidades sociales y se apoya en un trabajo de sobrevivencia frente a las emergencias económicas y deudas sociales crónicas de la región, que trasciende el deseo individual y que marca profundamente sus usos inicuos ${ }^{47}$.

Recuérdese que nuestro orden constitucional no tolera que la injusticia social que emerge de la pobreza sea castigada con la destrucción de la unidad familiar, a través de diferentes medios, como la entrega del hijo ${ }^{48}$; ni que la entrega en estado de necesidad y desesperación sea calificada como abandono; de lo contrario, la mera tradición de un ser humano tendría efectos de adquisición y transmisión de su propiedad, legitimándose así la apropiación y tráfico de personas ${ }^{49}$.

En tal sentido, la defensa de la maternidad subrogada en base a la figura de la autonomía de la voluntad en las decisiones reproductivas, en el contexto social latinoamericano, al igual que en otros lares ${ }^{50}$, refuerza estereotipos limitantes, ennoblece la falta de otras oportunidades para la mujer que le permitan una retribución justa y legitima la realidad de las mujeres paridoras y el tráfico y venta de niños, que resultan rechazados por nuestro orden público internacional ${ }^{51}$.

Como señala una jurista norteamericana, los discursos contemporáneos sobre la liberación de la mujer y sus derechos reproductivos esconden inauditas formas de control social, interés de minorías en mantener sus privilegios, indiferencia respecto del bienestar de los niños y la denegación de justicia económica para muchos ${ }^{52}$.

En esa situación, sostener que gestar y dar a luz hijos ajenos resulta un factor de liberación femenina, en un plano de draconianas condiciones impuestas, anonimato registral y falta de efectos jurídicos y de comunicación en su relación materno filial, surge como una de las vindicaciones donde la mujer va contra sí misma ${ }^{53}$ y no se condice con los principios fundamenta-

47 Mir Candal, L. (2010). "La 'maternidad intervenida'. Reflexiones en torno a la maternidad subrogada”. Revista Red Bioética. Disponible en https://redbioetica.com.ar/wp-content/ uploads/2018/11/Leila.pdf.

48 Superior Tribunal de Justicia (STJ), provincia de Corrientes, causa "xx y xx y xx s/ prevencional", del 12-12-2007, La Ley 2008-B-397.

49 Cámara de Apelaciones en lo Civil y Comercial (CACiv. y Com.), sala I, Posadas, provincia de Misiones, causa "I., S. c/ B., M. y otro", del 16-3-2007, La Ley Litoral 2007-656.

50 Berti García, B.; Berti García, M. y Nasazzi, F. "Las cláusulas de los contratos de alquiler de vientre en la India: explotación de la mujer y comercialización de la vida humana". El Derecho 24-8-2012.

51 Galli Fiant, M. M. “Gestación por sustitución. Con los ojos abiertos y los pies sobre la tierra”. Microjuris MJD6195, del 11-3-2013.

52 Glendon, M. A. "Familia y sociedad: las organizaciones internacionales y la defensa de la familia". El Derecho 174-1145.

53 Calvo Charro, M. (2010). "Esclavitud y liberación de la mujer en la hipermoderni- 
les de nuestro orden público internacional que tutelan específicamente a la mujer ${ }^{54}$.

\section{Orden público}

\section{1) Configuración}

La noción de "orden" nos ubica en las materias múltiples y en un principio de inteligibilidad que las comprende en su similitud y diversidad, según corresponda, obteniendo así las cosas una nueva comprensión desde su particularidad y forma colectiva, para entenderlas en el todo orgánico y sus características intrínsecas.

Lo "público" no se puede identificar con la pluralidad de las relaciones humanas cuantificables, ni con el interés estatal diferenciado, sino con la múltiple actividad humana de alteridad en una unidad de sentido y de destino del todo social y sus fines propios ${ }^{55}$.

La noción de orden público, aun cuando se indica que puede remontarse hasta el Derecho romano, en nuestro sistema codificado se siguió la expresión en el sentido establecido en el Code Napoleón, con dos connotaciones relevantes; en primer término, que sus ramificaciones se extienden a las diversas áreas del Derecho; y, en segundo lugar, que resulta ineludible y con fuerza imperativa para las magistraturas, de acuerdo a su razón ordenadora de la sociedad.

En la fuente jurídica francesa se pueden distinguir notas que ubican el concepto de orden público en vinculación con la noción subjetiva de "interés", con la categoría de normas de "policía", y con áreas que atañen al interés público que resultan inderogables por los particulares en sus convenciones, ya sea por motivos de humanidad, paz o armonía social, de organización de la sociedad, protección de terceros o de buenas costumbres.

Sin embargo, en nuestro ordenamiento jurídico, como consecuencia de nuestro devenir histórico y las características de nuestro medio social, la noción de orden público asumió otras notas relevantes, como su asociación "objetiva" a los fundamentos de la sociedad, como un conjunto de principios de diverso orden vinculados a la conservación de la organización social, re-

dad". Nueva Revista de Política, Cultura y Arte, disponible en https://www.nuevarevista.net/ esclavitud-y-liberacion-de-la-mujer-en-la-hipermodernidad/.

54 Art. 75, incs. 22 y $23 \mathrm{CN}$; y art. 4.2 Convención sobre la Eliminación de todas las Formas de Discriminación Contra la Mujer; arts. $2^{\circ}, 3^{\circ}$ y $4^{\circ}$, Ley $\mathrm{N}^{\circ} 25.929$ (de parto humanizado).

55 Ortiz Bustos, B. "Reflexiones acerca del orden público". La Ley 1981-D-834. 
lacionados con el Derecho Natural y con las directrices consecuentes de las normas positivas ${ }^{56}$.

Un criterio del Derecho Natural que rige en nuestro orden público en protección de las instituciones del Derecho de Familia, se configuró en el reconocimiento jurisprudencial del derecho deber natural de los padres a tener bajo su cuidado a los hijos, criarlos, alimentarlos y educarlos, según su condición y fortuna, manteniéndose, de ser posible, los vínculos consolidados de las relaciones parentales constituidas a partir de la procreación ${ }^{57}$.

También, se lo distinguió al orden público de la noción limitante de "policía”, para ubicarlo en un sentido nuevo, de acuerdo a un todo orgánico, al considerar que la sociedad no es una suma de individualidades, sino que funciona como un todo que tiende al bien comunitario, por lo que el orden público asegura la subsistencia de las instituciones fundamentales de la comunidad y expresa una resistencia a la arbitrariedad o desvíos pasajeros en la vida social ${ }^{58}$.

En nuestro medio incluso opera como una articulación de las personas y sociedades privadas con el bien común político, con el fin de ordenar los pactos y conductas al fin político de la sociedad, integrando el orden público un núcleo inmutable en la protección de las condiciones sustanciales de humanidad de los hombres y de las comunidades naturales que integra, fundadas en la convivencia, arraigo, inclinaciones particulares y bienestar común ${ }^{59}$.

Por consiguiente, las declaraciones legislativas en ese sentido resultan superabundantes, ya que una normativa será de orden público, por su relación sustantiva con la res pública y los principios generales que la delimitan en los diferentes ámbitos de actividad común, más allá que exista tal declaración o se la declame en la deliberación legislativa o en las alegaciones de intereses privados ${ }^{60}$.

\section{2) Alcances}

Por lo tanto, el orden público interno de nuestro país se puede distinguir como un conjunto de principios de orden superior, políticos, económicos,

56 Basset, Ú. C. (2007), "Peculiaridades del orden público en el régimen argentino". Revista de Derecho Privado y Comunitario. Tomo 3. Santa Fe. Rubinzal Culzoni, 419-454.

57 Corte Suprema de Justicia de la Nación (CSJN), Fallos: 328:2870 “S., C. s/ adopción" (2005), considerando $6^{\circ}$ del voto de los Dres. Petracchi, Belluscio y Maqueda y considerando $6^{\circ}$ del voto de los Dres. Highton de Nolasco y Lorenzetti.

58 Basset, Ú. C. Ob. cit., 58.

59 Sodero, E.; Vigo, R. L. “Orden público y orden público jurídico”. La Ley 2015-F-1077.

60 Ortiz Bustos, B. Ob. cit., 57. 
culturales y religiosos, plasmados directa o indirectamente en leyes y reglamentaciones, a los cuales la sociedad considera vinculada la existencia y conservación de la organización social establecida, como las regulaciones que fijan el estado y capacidad de las personas y las que organizan la institución de la familia ${ }^{61}$.

Cabe destacar que el orden público como conjunto de principios en que se cimenta la organización social, con el particularismo de cada país, al destacar la trascendencia de las instituciones que abarca, las pone por encima de la voluntad individual de los contratantes y no permite la renuncia de derechos que fueron conferidos para cumplir una función social, como los derechos de los progenitores para el cumplimiento de sus deberes con respecto al cuidado y desarrollo de sus hijos ${ }^{62}$.

En esa inteligencia, son de orden público y prevalentes en relación a la normativa civil los derechos, declaraciones y garantías que reconoce la Constitución Nacional y los Tratados Internacionales de Derechos Humanos con jerarquía constitucional; $y$, por ende, lo que las reglas constitucionales y/o convencionales ordenan no resulta susceptible de ser dejado de lado por la voluntad de los contratantes ni por actos de los poderes constituidos ${ }^{63}$.

Recuérdese que las garantías constitucionales existen y protegen de manera efectiva a las personas por el solo hecho de estar consagradas por el constituyente y en forma independiente a lo que las leyes y reglamentaciones regulen ${ }^{64}$; de lo contrario, la Constitución Nacional enunciaría derechos huecos, un conjunto de buenos consejos, quedando la determinación de su contenido protectorio librado al arbitrio del legislador ${ }^{65}$.

Asimismo, en nuestro orden público rige el principio de supremacía constitucional (art. 31, CN), por lo que las decisiones de las magistraturas deben estar orientadas por los preceptos constitucionales y por el Derecho Natural que los preside, ya que nuestra Carta Magna manda que se apliquen prioritariamente sus propósitos, entre ellos, afianzar la justicia ${ }^{66}$.

61 Salvat, R. M. (1954), Tratado de Derecho Civil. Parte General. Tomo I. 10 a edición actualizada por Víctor N. Romero del Prado. Buenos Aires. TEA, 148-149.

62 Llambías, J. J. (1995). Tratado de Derecho Civil. Parte General. Tomo I. 16 a edición actualizada por Patricio Raffo Benegas. Buenos Aires. Perrot, 158-166.

63 Manili, P. L. "La Constitución Nacional es de orden público y no admite acuerdo en contrario". La Ley 2004-D-1015.

64 Corte Suprema de Justicia de la Nación (CSJN), Fallos: 315:1492 "Ekmekdjián" (1992), considerando $31^{\circ}$ del voto de los Dres. Cavagna Martínez, Barra, Fayt, Nazareno y Boggiano.

65 Corte Suprema de Justicia de la Nación (CSJN), Fallos: 332:2043 "Pérez" (2009), considerandos $5^{\circ}$ y $6^{\circ}$ del voto de los Dres. Lorenzetti, Petracchi, Maqueda y Zaffaroni.

66 Casares, T. D. (1980). "Prudentia Iuris". Revista Prudentia Iuris, N 1, 8. 
En otros términos, el orden público no se configura con esquemas ideales, consensos de la clase dirigente, la sensación de la mayoría de la población, ni con el abandono fragrante del respeto a la ley, sino que debe surgir de las entretelas de la conformación comunitaria del país, con su historia, estilo de vida y valores, como una barrera orientada a prohibir aquello que destruye la convivencia social ${ }^{67}$.

Si bien el orden público tiene una apreciación variable de los hechos, en torno a los aspectos temporales y espaciales propios de una determinada comunidad, posee un contenido mínimo invariable que garantiza el desenvolvimiento social de la comunidad política en su teleología natural, a partir de pautas de continuidad cultural, perdurabilidad de las instituciones, reciprocidad y previsión en los intercambios y tutela especial de las personas vulnerables.

Recuérdese que aun cuando los primeros principios universales son los mismos para todos los hombres, los preceptos secundarios derivados de la ley natural pueden sufrir variaciones por las condiciones añadidas a la situación concreta o por impedimentos del mandato particular en su inteligibilidad, en la ejecución o en las costumbres ${ }^{68}$.

El orden público no se puede concebir como una acumulación de derechos y libertades, que, a manera de fantasía y ambición del hombre, tiene como límite los derechos de los demás, ya que ello lo delimitaría a partir de la fuerza o de la astucia, en una grotesca caricatura, despedazada por las disputas individuales y por la imposición del poder inicuo.

Lo que interesa en el ejercicio de los derechos no es su límite sino su fundamento, que no se encuentra al arbitrio de autonomías individuales, costumbres o mayorías injustas, sino que se reconoce en el señorío de los deberes, en cuyo cumplimiento se encuentra la medida de la dignidad humana y los principios universales que la fundan en su razón de ser69.

Deberes que se vinculan de modo sustancial a la naturaleza filial del ser humano y al reconocimiento del don originario en la esencia de su recto comportamiento social ${ }^{70}$.

Reitérese que al orden público no se lo puede despojar de su connotación política, que excede la normativa civil vigente, ya que tiende al logro de los fines esenciales de la sociedad políticamente organizada, en las consi-

67 Conte-Grand, J. (2009). "La mutación del orden público y su incidencia en el sistema de derecho privado: reflexiones en los umbrales del bicentenario patrio". Revista Prudentia Iuris $\mathrm{N}^{\circ} 66 / 67,249-269$.

68 Santo Tomás de Aquino (1995). Suma de Teología. Parte I-II C. 94 a. 4. Madrid. BAC.

69 Casares, T. D. (1981). "El orden civil”. Revista Prudentia Iuris, No 2, 7-16.

70 Francisco (2013). Lumen fidei. Sobre la fe. $1^{a}$ edición. Tipografía Vaticana, punto 19, 23. 
deraciones relacionales de alteridad que mantienen las personas dentro de una comunidad política.

Por ello, la renuncia o abdicación de un derecho personalísimo en el marco de un contrato se encuentra con la valla del orden público, que rechaza cualquier acuerdo que implique la deshumanización o cosificación de la persona involucrada, ya que al aforismo volenti non fit injuria (no se comete injusticia con quien actuó voluntariamente), se lo puede definir como la "la pantalla de todas las iniquidades y explotaciones"71.

En el Derecho de Familia, aun con las modificaciones legislativas producidas en los últimos decenios, se mantiene la preponderancia del orden público, en atención a la protección especial que se reconoce a la familia como comunidad primigenia de la sociedad, basada en lazos de orden paterno y materno filial inalienables, que reposan en la solidaridad, asistencia y respeto entre sus integrantes para la satisfacción de sus necesidades primarias $^{72}$.

Por ello, los lazos de parentesco junto con la comunidad de vida son elementos preexistentes al ordenamiento estatal que se encuentran protegidos constitucionalmente y no pueden ser ensanchados o alterados por deseos individuales, más allá de la creación de vínculos jurídicos tendientes a darle una familia a quien carece de ella o de sus funciones esenciales ${ }^{73}$.

En una comunidad, como lo es el caso de la familia, los miembros se vinculan por una relación personalísima, y, por lo tanto, sus miembros no son fungibles ni intercambiables ${ }^{74}$.

En ese sentido, el orden público familiar veda convenciones en contra de las normas que regulan determinadas instituciones referentes a la familia, como la filiación y el parentesco.

La voluntad individual puede crear actos jurídicos familiares o impulsar acciones de estado, pero no es reguladora de los derechos y obligaciones dispuestos por el ordenamiento legal; tampoco puede borrar la desigualdad subsistente por la imposibilidad de procrear, por naturaleza, de las uniones

71 Llambías, J. J. “Anteproyecto de Código Civil de 1954 para la República Argentina. Universidad Nacional de Tucumán 1968, nota al artículo 1020”, citado en De Lorenzo, M. F. "Contratos, derechos fundamentales y dignidad de la persona humana". La Ley 2011-E-1258.

72 Corte Suprema de Justicia de la Nación (CSJN), Fallos: 315:549 "Coppola” (1992), considerandos $7^{\circ}$ y $8^{\circ}$ del voto del Dr. Fayt.

73 De Montalvo Jääskeläinen, F. (2017). "Una reflexión sobre la oportunidad de regular la maternidad subrogada desde la perspectiva de la familia como institución garantizada constitucionalmente", disponible en https://repositorio.comillas.edu/xmlui/handle/11531/23946.

74 Corte Suprema de Justicia de la Nación (CSJN), Fallos: 344:1151 "Shi, Jinchui" (2021), considerando $10^{\circ}$ del voto de los Dres. Maqueda y Rosatti. 
homosexuales, ni puede resignar funciones emergentes del estado de familia atribuido por el Derecho vigente ${ }^{75}$.

Recuérdese que en nuestro orden público todo niño tiene derecho a que se le proporcionen, tanto a él como a su madre, cuidados especiales de atención prenatal y posnatal; y para su desarrollo pleno de la personalidad necesita, de ser posible, crecer al amparo y bajo la responsabilidad de sus padres, y no separarse al niño de corta edad de su madre ${ }^{76}$.

En nuestro orden jurídico, las medidas de protección integral de los niños, para garantizar sus condiciones dignas de vida, se extienden a la madre y al padre durante el embarazo, el parto y el período de lactancia, para asegurar el adecuado desarrollo de su embarazo y la crianza de su hijo ${ }^{77}$.

Nuestro orden público distingue, en los vínculos jurídicos, la actividad que resulta, per se, inseparable de la persona humana y su dignidad ${ }^{78}$. Dignidad humana intrínseca de la que existe un solo modo de concebirla, so pena de causar la degradación del hombre dentro del orden de la creación, y que dimana directamente de las prescripciones de la ley eterna, por lo que la disposición del legislador o gobernante que la desconociese sería arbitrariedad y violencia ${ }^{79}$.

El respeto a la dignidad humana configura nuestro orden público, que reacciona contra los postulados de la ideología del mercado global y los peligros de la investigación científica, en protección de la persona humana y sus libertades, como principio vivificador de los más variados campos jurídicos, como ser el derecho de contratación, la regulación de las relaciones familiares y la tutela, en general, de la persona en condiciones de vulnerabilidad ${ }^{80}$.

Es así que el derecho a preservar desde su origen todos los elementos que hacen a la identidad de la persona, reconocido en la Convención Internacional de los Derechos del Niño, hace a la dignidad de la persona, no está subordinado a otros derechos y en el mencionado derecho se involucra el establecimiento y reconocimiento de la filiación en sus diferentes fuentes (por naturaleza, adoptiva y por técnicas de reproducción humana asistida), su nacionalidad y sus componentes culturales ${ }^{81}$.

75 Medina, G. "Orden público en el derecho de familia”. La Ley 2015-F-742.

76 Principios 4 y 6 de la Declaración de los Derechos del Niño.

77 Art. 18, Ley $\mathrm{N}^{\circ} 26.061$.

78 Corte Suprema de Justicia de la Nación (CSJN), Fallos: 333:2306 “Álvarez" (2010), considerando $6^{\circ}$ del voto de los Dres. Fayt, Petracchi, Maqueda y Zaffaroni.

79 Massimino, L. (2013). "La dignidad de la persona como principio del derecho público". Revista Rap, Año XXXV, No 418, Buenos Aires.

80 Mayo, J. "Persona humana y dignidad. El orden público humanista". Revista Derecho de Familia y de las Personas 2010-238.

81 Najurieta, M. S. (2016). "Principios y caracteres del derecho internacional privado de la infancia con especial referencia a las disposiciones del Código Civil y Comercial de la 
En efecto, se denomina "cláusula argentina" a los términos utilizados en la redacción final del articulado referente al derecho a la identidad en la Convención Internacional de los Derechos del Niño, ya que fue el resultado del debate instado por la delegación argentina, por lo que una figura similar al parto anónimo en la filiación biológica no se podría receptar en nuestro ordenamiento jurídico, como tampoco el fraude de inscribir a un hijo como propio cuando no lo es, ni otras figuras que afecten el derecho a conocer sus orígenes en la filiación adoptiva o en las técnicas de reproducción humana asistida $^{82}$.

En esta orientación, hay doctrina judicial que ante un menor de edad que no había sido inscripto por su madre biológica y que se había otorgado su guarda por acta notarial a los pretensos padres adoptivos, ordena la adopción plena demandada, pero con la inscripción registral del niño como hijo de su madre de sangre y no como si la misma fuera desconocida, en resguardo del derecho a su identidad ${ }^{83}$.

\section{Orden público internacional}

\section{1) Caracterización}

El orden público internacional se puede caracterizar como los principios jurídicos del Derecho argentino que actúan como cláusula de reserva frente a las soluciones del Derecho extranjero, es decir, que funciona como una cláusula de faz negativa, al hacer excepción a la aplicación del Derecho foráneo cuando este resulta contradictorio con los principios que rigen en el Derecho patrio ${ }^{84}$.

Por su parte, el artículo 2600 del Código Civil y Comercial de la Nación dispone, en forma clara, que las normas extranjeras aplicables deben ser excluidas cuando conducen a soluciones incompatibles con los principios fundamentales de orden público que inspiran nuestro ordenamiento jurídico.

Nación”. Revista Jurídica de Buenos Aires, Derecho Internacional Privado, Año 41, Nº 93. Abeledo Perrot, Facultad de Derecho - UBA, 140.

82 Gil Domínguez, A.; Famá, M. V.; Herrera, M. (2007). Ley de Protección Integral de Niñas, Niños y Adolescentes. Derecho Constitucional de Familia. $1^{a}$ edición. Buenos Aires. Ediar, 230 y 248.

83 Cámara en lo Civil, Comercial, Criminal y Correccional (CCiv. Com. Crim. y Corr.), Pergamino, provincia de Buenos Aires, causa "C., O. A. y otro", del 21-11-1996, La Ley Buenos Aires 1997-82.

84 Boggiano, A. (2006). Derecho Internacional Privado. Tomo I. $5^{\text {a }}$ edición. Buenos Aires. Abeledo Perrot, 439. 
Cabe destacar que no basta la contradicción con una norma o regulación particular, sino que debe resultar una lesión a principios generales inferidos de la legislación actualmente aplicable ${ }^{85}$, y de sus presupuestos de justicia, comprendiendo la totalidad del ordenamiento jurídico y los principios y garantías constitucionales, para obtener un resultado adecuado y evitar soluciones disvaliosas.

Ello significa que, por el orden público internacional, el Derecho extranjero resulta sometido, primero, al examen de compatibilidad, concreto y realista, con los principios y garantías de nuestra Constitución Nacional; y, luego, a la reserva de que no surjan obstáculos en los principios de la legislación y jurisprudencia imperante. Este examen del orden público internacional que incorpora el confronte con los derechos constitucionales evita la coexistencia de sistemas paralelos ${ }^{86}$.

Esta noción del orden público internacional, que se ubica en la última etapa del razonamiento conflictual, con la compatibilidad de la solución de la ley extranjera con los principios sociales, morales, religiosos y jurídicos del foro que inspiran su legislación y se encuentran determinados en una o variadas normas, lo revaloriza en la función de garantizar y otorgar efectividad a los derechos fundamentales.

Inclusive, hay principios que forman el sustrato mínimo común del orden público internacional, que son verdaderamente internacionales o ius cogens, que nuestro país debe aplicar independientemente de sus compromisos asumidos en tratados o de lo dispuesto en el Derecho Interno, por lo que esos principios imperativos de índole internacional exigen la conformidad de la normativa interna, en las variadas circunstancias de aplicación ${ }^{87}$.

Los principios que emanan de los tratados internacionales, especialmente aquellos que poseen jerarquía constitucional (art. 75 , inc. 22, CN), integran el orden público internacional, y su contenido obliga a las distintas autoridades administrativas, judiciales y legislativas, sus cláusulas son operativas y tienen fuerza vinculante tanto en lo interno como en lo internacional, siendo un eficaz instrumento de protección de los derechos fundamentales ${ }^{88}$.

85 CSJN, Fallos: 319:2779 "Solá" (1996), considerando $7^{\circ}$.

86 Perugini, A. M.; Ramayo, R.A., "Constitución Nacional, derecho extranjero y orden público". La Ley 1978-D-925.

87 Corte Suprema de Justicia de la Nación (CSJN), Fallos: 305:2150 "Cabrera" (1983), considerando $9^{\circ}$ del voto de los Dres. Gabrielli y Guastavino.

88 Bidart Campos, G. J. "La aplicación judicial de la Convención sobre los derechos del niño". El Derecho 150-514. 
Es decir, se aplica el principio plasmado en el tratado internacional o la solución del Derecho extranjero, aquella que asegure el grado más elevado de protección a las personas implicadas.

Sin perjuicio de ello, en los últimos tiempos, se toma un concepto reducido del orden público internacional, limitándolo a su contenido mínimo, de protección contra las ofensas a los derechos humanos, a fin de favorecer la cooperación internacional y evitar que objetivos que sólo se pueden lograr en un marco de auxilio universal se frustren por una presión particular en el contexto nacional ${ }^{89}$.

En efecto, las disposiciones actuales de Derecho Internacional Privado reflejan un pluralismo de objetivos, en balance y equilibrio, de previsibilidad y flexibilidad, con una clara orientación de justicia material, como en el primer párrafo del artículo 2631 del Código Civil y Comercial de la Nación, que mediante una técnica de puntos de conexión alternativos, imprime una inclinación, no hacia la validez del vínculo, sino hacia el pleno goce de los derechos fundamentales del hijo, con una posición preeminente del derecho a la identidad ${ }^{90}$.

En ese entendimiento, el orden público internacional en materia de Derecho de Familia se encuentra formado por un núcleo de cumplimiento imperativo con escaso margen para la autonomía de la voluntad, dándole preeminencia al valor de la previsibilidad; no obstante, en el caso de los derechos de la infancia, el mencionado marco de previsibilidad se debe efectuar con los ajustes necesarios para contemplar las necesidades de los niños, en su dinamismo existencial.

\section{2) Matices}

A su vez, el orden público internacional no sólo tiene una función de cláusula de reserva frente a la aplicación del Derecho extranjero, sino que constituye una herramienta de adaptación y coordinación de sistemas a fin de no frustrar los derechos fundamentales de los niños que se encuentran en situación de mayor vulnerabilidad por el fenómeno de las relaciones internacionales ${ }^{91}$.

En ese marco, en materia de filiación, el artículo 2634 del Código Civil y Comercial de la Nación tiende a la admisión de situaciones potencialmente problemáticas, con el enfoque del derecho fundamental a la estabilidad

89 Najurieta, M. S. "Orden público internacional y derechos fundamentales del niño". La Ley 1997-B-1436.

90 Najurieta, M. S. (2016). Principios y... Ob. cit., 148-149.

91 Ibídem, 162. 
del estado de familia, ya que cuando un estado de familia existe para un ordenamiento jurídico, la frustración de su reconocimiento en otro orden jurídico puede afectar los derechos fundamentales del niño (v. gr., situación de apátrida y de falta de personalidad jurídica, vinculación con su padre biológico, derechos emergentes de la responsabilidad parental y derechos sucesorios).

Los matices señalados en el orden público internacional en materia de familia permiten reconocer ciertos efectos consecuentes de una relación ya constituida en el extranjero que no puede ejercerse en nuestro país, pasando a ser un orden público atenuado, como en el reconocimiento de derecho de alimentos para los hijos o de una pensión por viudez para el cónyuge supérstite en un matrimonio poligámico ${ }^{92}$.

Por ello, no se impone la verificación de la regularidad de la situación de conformidad a las normas de conflicto del foro, sino que se acepta lo constituido en conjunto por el Derecho extranjero, con el único control de la compatibilidad de la situación con el orden público argentino, valorado en su núcleo mínimo de los principios en la materia, y especialmente, de los derechos consagrados en la Convención Internacional de los Derechos del Niño.

En mérito a lo expuesto, se impone el reconocimiento a todos los supuestos internacionales, en virtud de la no discriminación por razón de nacimiento y para evitar las consecuencias de colocar en una situación de extrema vulnerabilidad al niño al mantenerlo en un limbo legal, sin existencia ni relaciones jurídicas que lo protejan y le otorguen elementos de su identidad ${ }^{93}$.

Además, cuando el artículo 2634 del Código Civil y Comercial de la Nación indica expresamente que los principios que regulan las normas sobre filiación por técnicas de reproducción humana asistida integran el orden público, sin olvidar, como ya vimos, que la práctica de la gestación por encargo se diferencia conceptualmente de las mencionadas técnicas, ello revela un principio de reconocimiento de la filiación coherente con los parámetros establecidos en el artículo 562, a saber, que los nacidos mediante esa fuente de emplazamiento filial son hijos de la mujer que dio a luz y del comitente que prestó su consentimiento previo.

Por otro lado, hay que tener en cuenta el patrón común internacional, que rige en nuestro Derecho, del principio favor filii, que sin tener en cuenta

92 Boggiano, A. (2006). Ob. cit., 443; Iud, C. D. (2013). "Los matices del orden público internacional en las relaciones de familia", Revista de Derecho de Familia y de las Personas, Año V, No 8, 43-51.

93 Corte Interamericana de Derechos Humanos (CIDH), caso "Niñas Yean y Bosico vs. República Dominicana”, (2005), párrafos 175, 180 y 183. 
la edad del hijo, persigue una normativa orientada a la aplicación del derecho más favorable a la validez del reconocimiento de la filiación ${ }^{94}$.

Sin perjuicio de ello, el reconocimiento a todos los supuestos internacionales se encuentra limitado por el principio de orden público internacional que establece que la decisión redunde en beneficio del interés superior del niño; estándar que indica, en las circunstancias del caso, que el niño no puede perder elementos que hacen a la identidad de su persona, y, por lo tanto, de su dignidad inherente, ni tampoco omitir la detección de delitos de tráfico y venta de niños o sustitución de identidad ${ }^{95}$.

Además, el interés superior del niño no puede invocarse para legitimar la inobservancia de requisitos legales ${ }^{96}$, ni puede alegarse un interés superior del menor en forma aislada del interés del grupo familiar, entendido éste como el interés de sus componentes en una situación de interdependencia solidaria dentro de la familia ${ }^{97}$.

Esta exigencia resulta adecuada para que el interés superior del niño no se pueda convertir en estos casos en una especie de patente de corso que permita legalizar indiscriminadamente relaciones familiares que nacieron de una actuación ilícita ${ }^{98}$.

\section{3) Jurisprudencia internacional}

A su vez, jurisprudencia internacional en la temática, como los casos "Mennesson y Labassée contra Francia", resueltos en el año 2014, por el Tribunal Europeo de Derechos Humanos, fue presentada, en primera instancia, como un guiño positivo en favor de la gestación por sustitución, por ser uno de los modos contemporáneos de alcanzar la maternidad y la paternidad, ampliando así el terreno de las filiaciones y la pluralidad de las familias, otrora soslayadas ${ }^{99}$.

Sin embargo, después se señalaron dos factores particulares de esos fallos que minimizan los alcances de su doctrina; en primer lugar, que en

94 Boggiano, A. (2006). Ob. cit., 681-683.

95 Najurieta, M. S. (2016). Principios y... Ob. cit., 160 y 162.

96 Corte Interamericana de Derechos Humanos (CIDH), caso "Fornerón e hija vs. Argentina" (2012), párrafo 105.

97 Hernández, L. B.; Ugarte, L. A. "Régimen de comunicación parental interprovincial e interés del niño frente a la emergencia sanitaria”. La Ley 25-8-2020.

98 Arroyo Gil, A. (2020). "Gestación por sustitución: la dignidad humana en juego". Revista de la Facultad de Derecho. Bilbao. Universidad de Deusto, Volumen 68/2, 69. Disponible en https://revista-estudios.revistas.deusto.es/article/view/1944.

99 Herrera, M.; Lamm, E. "Un valiente fallo del TEDH sobre gestación por sustitución. Prohibir, silenciar, regular o fallar”. La Ley 2014-D-1165. 
ambos casos existía un vínculo genético entre uno de los comitentes y los nacidos; y en segundo término, que el sistema francés se regía por la máxima fraus omnia corrumpit (el Derecho no puede reconocer situaciones originadas en hechos fraudulentos), por lo que no reconocía efectos al acto extranjero, ni permitía tales efectos por otras vías proporcionadas por el sistema, como recurrir a la adopción, posesión de estado u otros institutos jurídicos, para hacer valer el emplazamiento filial ${ }^{100}$.

De modo que no cabe inferir de los casos concretos resueltos por el TEDH un pronunciamiento general sobre la legitimidad de la gestación por sustitución, ni deducir una obligación general de reconocer las relaciones de filiación establecidas en el extranjero por el contrato de maternidad subro$\operatorname{gada}^{101}$.

Es decir, en estos dos casos se aprecia más un rechazo del tribunal europeo a la idea de fraude a la ley francesa, que impedía en forma absoluta el vínculo filial cuando efectivamente eran los padres biológicos del hijo, con la consecuente desprotección humanitaria del niño, y no a la noción de orden público francés.

Ello se vio corroborado en fallos posteriores del TEDH en la materia, como en el caso "Paradiso y Campanelli vs. Italia", resuelto por la Gran Sala el 24 de enero de 2017, donde se avaló la actuación de las autoridades italianas que privaron de la paternidad a los comitentes que actuaron en forma contradictoria y que carecían de vínculo biológico con el niño en una maternidad subrogada internacional, en circunstancias que indicaban la posible comisión de delitos ${ }^{102}$.

Además, en el caso mencionado, el TEDH consideró expresamente que no existe un derecho a la maternidad o paternidad que nazca de la mera voluntad o de la autonomía y desarrollo personal, plasmado en un "proyecto paternal", ni que sea título suficiente para inscribir hijos adquiridos a consecuencia de contratos de gestación por sustitución ${ }^{103}$.

El reconocimiento de tales aspectos fue reiterado en la resolución del 10 de abril de 2019 del TEDH, en la Opinión Consultiva planteada por las

100 Álvarez González, S. (2017). “Gestación por sustitución y orden público”. InDret Revista para el Análisis del Derecho. Barcelona, disponible en www.indret.com.

101 Rubaja, N. "Un nuevo caso sobre gestación por sustitución transfronteriza que llega al Tribunal Europeo de Derechos Humanos. El impacto de los lineamientos del tribunal en la jurisprudencia francesa y los interrogantes pendientes". Revista de Derecho de Familia 20211-217.

102 Arroyo Gil, A. (2020). Ob. cit., 62/63.

103 Valero Heredia, A. (2019). "La maternidad subrogada: un asunto de derechos fundamentales”. Teoría y Realidad Constitucional, N 43, pp. 421-440. 
autoridades de casación francesas ${ }^{104}$, y en casos contenciosos posteriores ${ }^{105}$, donde se consideró que los países europeos no están obligados a registrar en el acta de nacimiento de un niño nacido por maternidad subrogada a la madre no biológica que surge del certificado de nacimiento extranjero, siempre que el reconocimiento se pueda hacer por otras vías, como mediante el proceso judicial de adopción.

Por último, en el caso reciente "Valdís Fjölnisdóttir y otros vs. Islandia", resuelto el 18 de mayo de 2021, la Corte europea encontró justificada la interferencia en la vida familiar y privada de las demandantes, donde las autoridades de Islandia, aun cuando dispusieron el acogimiento familiar del niño y reconocieron su ciudadanía islandesa, rechazaron la registración parental intencional de la pareja homosexual femenina islandesa, sin vínculos genéticos con el niño concebido mediante un contrato de maternidad subrogada en Estados Unidos ${ }^{106}$.

Es así que, teniendo en cuenta la prohibición de los convenios de maternidad subrogada en el orden jurídico islandés, el tribunal consideró necesaria la medida para proteger la moralidad y los derechos de otros, máxime cuando fue acompañado por esfuerzos de contrabalanceo suficientes para aliviar los efectos negativos del rechazo; si bien indicó que el interés superior de niño es de fundamental importancia, sostuvo que no puede sobrepasar los principios legales fundamentales del régimen de filiación.

\section{Conclusión}

Más allá de la polisemia usual del término "maternidad”, su identidad al vientre o útero de la mujer, su estado de embarazo, parto y posterior período de lactancia, resulta un dato perenne en las diversas culturas y aconteceres históricos, que deviene potenciado en las bases jurídicas latinoamericanas ${ }^{107}$, que no puede ser ignorado jurídicamente sin ocasionar un

104 Scotti, L. B. “Gestación por sustitución: acerca de la opinión consultiva del Tribunal Europeo de Derechos Humanos”. La Ley 2019-C-962.

105 Marrama, S. (2020). Prácticas abusivas en convenios de maternidad subrogada. Buenos Aires. Erreius. Temas de Derecho de Familia, Sucesiones y Bioética.

106 Serdán, F. (2021). "Nueva decisión del Tribunal Europeo de Derechos Humanos sobre maternidad subrogada”. Centro de Bioética, Persona \& Familia, disponible en https:// centrodebioetica.org/nueva-decision-del-tribunal-europeo-de-derechos-humanos-sobre-maternidad-subrogada.

107 Kemelmajer de Carlucci, A. "El derecho humano a conocer el origen biológico y el derecho a establecer vínculos de filiación (a propósito de la decisión del Tribunal Europeo de Derechos Humanos del 13-2-2003, en el caso 'Odiévre v. France')”. Revista de Derecho de Familia 2003-26-77. 
menoscabo sustancial en la dignidad inherente de las personas implicadas (madre e hijo) y sus derechos familiares.

Máxime, teniendo en cuenta la condición de particular vulnerabilidad en la que se encuentra una mujer en estado de embarazo ${ }^{108}$, y que debe abandonarse la noción de familia estructurada sobre bases potestativas de los padres que toman como objeto de posesión a sus hijos, para dar lugar a una concepción cercana al officium o la pietas de los primitivos cristianos, como función conjunta de la madre y el padre, que se origina en la unión matrimonial ${ }^{109}$.

De esta manera, desde la mirada sistémica de nuestros principios de orden público, con la correspondiente preeminencia de los derechos y garantías constitucionales, sus bases ius naturalistas y de bien común, y las expresiones legislativas consecuentes ${ }^{110}$, surge la prohibición general por nuestro ordenamiento jurídico de los acuerdos de gestación sustitutiva y la necesidad de someter el acto irregular a las normas imperativas que se tratan de eludir.

En coherencia con ello, nuestro orden público internacional rechaza las normas y convenciones extranjeras de maternidad subrogada, que conducen a resultados incompatibles con los principios fundamentales de orden público, más allá de los matices vistos del Derecho Internacional Privado, que pueden justificar la admisión de situaciones potencialmente anómalas, en pos de la estabilidad del estado de familia y para no situar al niño en una situación de desamparo.

Postura de cooperación internacional de nuestro ordenamiento jurídico, que se mantendrá siempre que no aparezcan elementos conducentes de una actuación delictual, como aquellos que configuren los crímenes de tráfico y venta de niños o de trata de mujeres.

La maternidad subrogada construye familias a través de un mercado global, donde hay todo un entramado económico, más allá de la existencia del llamado "altruismo" de la gestante, que comienza con las agencias multinacionales de fertilización artificial intervinientes y que termina transformando a la mujer en una incubadora humana y, al niño, en un producto que no guarda relación con ella ${ }^{111}$.

108 Corte Interamericana de Derechos Humanos (CIDH), caso "Gelman vs. Uruguay" (2011), párrafo 97.

109 Álvarez, A. (1985). "Patria potestad. Hijos extramatrimoniales". En AA. VV. Cursos de Cultura Universitaria. Volumen II "Educación y Familia”. Buenos Aires. Instituto de Cultura Universitaria UCA, 251-252.

110 Arts. 12, 562, 588, 594, 595, 607 inc. B y 611 Código Civil y Comercial de la Nación; arts. $3^{\circ}, 9^{\circ}, 11$ y 18 Ley $\mathrm{N}^{\circ} 26.061$; arts. $2^{\circ}, 3^{\circ}$ y $4^{\circ}$ Ley $\mathrm{N}^{\circ} 25.929$, entre otras.

111 López Guzmán, J. (2017). “Dimensión económica de la maternidad subrogada ('Habi- 
Como dice un filósofo actual, "si un hombre recurre a una mujer para ser padre, la reduce a ser una porta-matriz, la convierte en la incubadora de su delfín. La paternidad es siempre oblicua. Sucede, comienza con algo distinto a sí misma, a saber, el deseo del otro sexo, un movimiento de integridad hacia su misterio, sin preservarse nada"112.

En definitiva, los menosprecios y quiebres jurídicos que resultan consecuencia directa de la maternidad subrogada justifican el rechazo de la figura en nuestro ordenamiento jurídico, y de forma coherente, nuestro orden público internacional tampoco avala la gestación por encargo extranjera, con las modulaciones propias que le imprimen a la materia, las relaciones internacionales de colaboración entre países y el Derecho Internacional Humanitario.

Resultaría paradójico suponer que existiendo mandato constitucional y convencional en un sentido determinado, se entendiera como un comportamiento legítimo y coherente con nuestro orden público internacional y sus bases de justicia material, el contrario a la creación de condiciones que aseguren a la mujer embarazada y al niño que alumbra, la vigencia y efectividad de sus derechos fundamentales ${ }^{113}$.

\section{Bibliografía}

Albert, Marta (2017). "La explotación reproductiva de mujeres y el mito de la subrogación altruista: una mirada global al fenómeno de la gestación por sustitución". Cuadernos de Bioética XXVIII, 2. Madrid, España. Asociación Española de Bioética y Ética Médica, 177-197.

Ales Uría, Mercedes, "La maternidad deconstruida: gestación por sustitución con ovodonación”. Revista Derecho de Familia y de las Personas 2017-243.

Ales Uría, Mercedes. "Límites a la disposición sobre el propio cuerpo a partir de un concepto de Dignidad Humana fundante”. La Ley 2017-B-888.

Ales Uría, Mercedes. "La maternidad determinada por acuerdo de partes". El Derecho 245-1054.

Álvarez, Atilio (2012). La adopción, disponible en la biblioteca digital de la UCA, https://repositorio.uca.edu.ar.

taciones en alquiler')". Cuadernos de Bioética XXVIII, 2. Madrid, España. Asociación Española de Bioética y Ética Médica, 199-218.

112 Hadjadj, F. (2021). "La paternidad aparece más que nunca como algo prodigioso". Entrevista publicada en el diario Le Figaro, disponible en https://eldebatedehoy.es/noticia/ entrevista/11/06/2021/fabrice-hadjadj/.

113 Arts. 15, 75 inc. 22 y 23 Constitución Nacional; art. $4^{\circ}$ Declaración Universal de Derechos Humanos; arts. 7.1 y 8.1 Convención Internacional de Derechos del Niño; arts. 4.2 y $6^{\circ}$ Convención sobre la Eliminación de todas las Formas de Discriminación contra la Mujer, Convenio 29 de la OIT sobre el trabajo forzoso, entre otros. 
Álvarez, Atilio (1985). "Patria potestad. Hijos extramatrimoniales". En AA. VV. Cursos de Cultura Universitaria. Volumen II "Educación y Familia". Buenos Aires. Instituto de Cultura Universitaria UCA, 247-256.

Álvarez de Toledo Quintana, Lorenzo (2014). "El futuro de la maternidad subrogada en España: entre el fraude a la ley y el correctivo de orden público internacional”. Cuadernos de Derecho Transnacional, Vol. 6, No 2, 5-49.

Álvarez González, Santiago (2017). “Gestación por sustitución y orden público”. InDret Revista para el Análisis del Derecho. Barcelona, disponible en www.indret.com.

Andorno, Roberto. "La selección embrionaria en la fecundación in vitro: el desafío de la nueva eugenesia". Revista de Derecho de Familia y de las Personas 2010-229.

Arendt, Hannah (2016). La condición humana. $1^{a}$ edición mejorada. Buenos Aires. Paidós.

Arroyo Gil, Antonio (2020). "Gestación por sustitución: la dignidad humana en juego". Revista de la Facultad de Derecho. Universidad de Deusto. Bilbao, Volumen 68/2, 41/73. Disponible en https://revista-estudios.revistas.deusto.es/article/ view/1944.

Astesiano, María Milagros (2017). La vulnerabilidad en el derecho privado: los nuevos huérfanos genéticos. Documento inédito perteneciente al Proyecto IUS 3/16, Facultad de Derecho de la Pontificia Universidad Católica Argentina, disponible en http://bibliotecadigital.uca.edu.ar.

Basset, Úrsula C.; Ales Uría, M. "Legislar sobre la maternidad subrogada". La Ley 2018-C-798.

Basset, Úrsula C., "El consentimiento informado y la filiación por procreación asistida en el Código Civil y Comercial". La Ley 14-7-2015 p. 1.

Basset, Úrsula C. (2007). "Peculiaridades del orden público en el régimen argentino". Revista de Derecho Privado y Comunitario. Tomo 3. Santa Fe. Rubinzal Culzoni, 419-454.

Bellver Capella, Vicente (2015). “Nuevas tecnologías? Viejas explotaciones. El caso de la maternidad subrogada internacional". Revista de Filosofía $\mathrm{N}^{\circ} 11$. Valencia, España, 19-52.

Bergoglio, Jorge Mario. "Algunas reflexiones sobre el Ejercicio de la Justicia hoy”. El Derecho 209-1096.

Bernanos, Georges (1989). La libertad, ¿para qué? Madrid. Encuentro.

Berterreix, María Laura. "Comentario a un fallo desalentador sobre las técnicas de reproducción humana asistida”. La Ley 21-12-2020.

Berti García, Bernardita; Berti García, Milagros y Nasazzi, Fernando. "Las cláusulas de los contratos de alquiler de vientre en la India: explotación de la mujer y comercialización de la vida humana". El Derecho 24-8-2012.

Bidart Campos, Germán J. "La aplicación judicial de la Convención sobre los Derechos del niño". El Derecho 150-514.

Bobbio, Norberto (1991). El tiempo de los derechos. Madrid. Sistema.

Boggiano, Antonio (2006). Derecho Internacional Privado. Tomo I. $5^{\text {a }}$ edición. Buenos Aires. Abeledo Perrot.

Borges, Jorge Luis (2017). Borges esencial. Real Academia Española y Asociación de Academias de la lengua española. Barcelona. Alfaguara. 
Bueres, Alberto J. -Director- (2015). Código Civil y Comercial de la Nación, analizado, comparado y concordado. $3^{\mathrm{a}}$ reimpresión. Buenos Aires. Hammurabi.

Calvo Charro, María (2010). "Esclavitud y liberación de la mujer en la hipermodernidad". Nueva Revista de Política, Cultura y Arte. España, disponible en https://www. nuevarevista.net/esclavitud-y-liberacion-de-la-mujer-en-la-hipermodernidad/.

Casares, Tomás D. (1980). "Prudentia Iuris". Revista Prudentia Iuris, No 1, 5-8.

Casares, Tomás D. (1981). "El orden civil". Revista Prudentia Iuris, No 2, 7-16.

Conte-Grand, Julio (2009). "La mutación del orden público y su incidencia en el sistema de derecho privado: reflexiones en los umbrales del bicentenario patrio". Prudentia Iuris $\mathrm{N}^{\circ}$ 66/67, 249-269, disponible en http://bibliotecadigital.uca.edu.ar.

De Lorenzo, Miguel Federico. "Contratos, derechos fundamentales y dignidad de la persona humana”. La Ley 2011-E-1258.

De Montalvo Jääskeläinen, Federico (2017). "Una reflexión sobre la oportunidad de regular la maternidad subrogada desde la perspectiva de la familia como institución garantizada constitucionalmente", disponible en https://repositorio.comillas.edu/xmlui/handle/11531/23946.

Di Pietro, Alfredo (1999). Derecho Privado Romano. $2^{\mathrm{a}}$ edición. Buenos Aires. Depalma.

Ekman, Kajsa Ekis (2017). El ser y la mercancía. Prostitución, vientres de alquiler y disociación. Barcelona. Bellaterra.

Esquilo (2000). Agamenón. Las Coéforas. Las Euménides. Madrid. Gredos.

Etcheverry, Juan Bautista (2017). "Rule of law y la discrecionalidad judicial: compatibilidad y recíproca limitación”. Revista Derecho del Estudio No 36, 3-21.

Etcheverry, Juan Bautista. "Causas y naturaleza de la discrecionalidad judicial en la interpretación y aplicación del derecho". Jurisprudencia Argentina 27-7-2011.

Famá, María Victoria. "El orden público internacional argentino ante la filiación por técnicas de reproducción humana asistida: normativa vigente y solución proyectada”. Jurisprudencia Argentina del 19-12-2012, 3.

Francisco (2013). Lumen fidei. Sobre la fe. $1^{\mathrm{a}}$ edición. Tipografía Vaticana.

Francisco (2016). El nombre de Dios es Misericordia. Una conversación con Andrea Tornielli. $2^{\mathrm{a}}$ edición. Buenos Aires. Planeta.

Galli Fiant, María Magdalena. "Gestación por sustitución. Con los ojos abiertos y los pies sobre la tierra”. Microjuris MJD6195, del 11-3-2013.

Garibo Peyró, Ana-Paz (2017). "El interés superior del menor en los supuestos de maternidad subrogada". Cuadernos de Bioética XXVIII, $2^{\circ}$. Madrid, España. Asociación Española de Bioética y Ética Médica, 245-259.

Gil Domínguez, Andrés; Famá, María Victoria; Herrera, Marisa (2007). Ley de Protección Integral de Niñas, Niños y Adolescentes. Derecho Constitucional de Familia. $1^{\text {a }}$ edición. Buenos Aires. Ediar.

Glendon, Mary Anne. "Familia y sociedad: las organizaciones internacionales y la defensa de la familia". El Derecho 174-1145.

Gómez, Julio L. "Cuestiones de la identidad y del emplazamiento filiatorio de un niño nacido por gestación por sustitución”. Revista Derecho de Familia y de las Personas 2019-79.

Grosso, Claudio. "El alquiler de vientre: su ilegitimidad". Revista Derecho de Familia $y$ de las Personas 2013-217. 
Hernández, Lidia B.; Ugarte, Luis A., "Régimen de comunicación parental interprovincial e interés del niño frente a la emergencia sanitaria”. La Ley 25-8-2020.

Herrera, Marisa; Lamm, Eleonora. "Un valiente fallo del TEDH sobre gestación por sustitución. Prohibir, silenciar, regular o fallar". La Ley 2014-D-1165.

Inca Garcilaso de la Vega (1996). Comentarios reales. $6^{a}$ edición. Buenos Aires. Plus Ultra.

Iud, Carolina D. (2013). "Los matices del orden público internacional en las relaciones de familia". Revista de Derecho de Familia y de las Personas, Año V, No 8 , 43-51.

Kemelmajer de Carlucci, Aída; Herrera, Marisa; Lamm, Eleonora; de la Torre, Natalia. "La gestación por sustitución en el Tribunal Europeo de Derechos Humanos. A propósito del caso 'Paradiso y Campanelli c/ Italia”'. La Ley 2017-B-27.

Kemelmajer de Carlucci, Aída. "El derecho humano a conocer el origen biológico y el derecho a establecer vínculos de filiación (a propósito de la decisión del Tribunal Europeo de Derechos Humanos del 13-2-2003, en el caso 'Odiévre v. France')". Revista de Derecho de Familia 2003-26-77.

Lafferriére, Jorge Nicolás. "Maternidad subrogada. Límites y dilemas de las tecnologías reproductivas”. La Ley 2016-A-1203.

Lahl, Jennifer (2018). "Embarazos contratados expuestos: los contratos de maternidad subrogada no protegen a las madres sustitutas y sus hijos". Disponible en https://centrodebioetica.org

Lewis, C. S. (2000). La abolición del hombre. Santiago de Chile. Andrés Bello.

López Guzmán, José (2017). "Dimensión económica de la maternidad subrogada ('Habitaciones en alquiler')". Cuadernos de Bioética XXVIII, 2. Madrid, España. Asociación Española de Bioética y Ética Médica, 199-218.

López Quintas, Alfonso (1987). "La manipulación del hombre a través del lenguaje", disponible en https://www.racmyp.es/docs/anales/A64-15.pdf.

Llambías, Jorge Joaquín (1995). Tratado de Derecho Civil. Parte General. T. I. $16^{\text {a }}$ edición actualizada por Patricio Raffo Benegas. Buenos Aires. Perrot.

Llambías, Jorge Joaquín. "La fecundación humana 'in vitro”. El Derecho 79-891.

Maino, Carlos A. G. (2014). "Pervivencia del rule of law en sociedades liquidas. Abordaje desde la perspectiva filosófico-política, jurídica y sociológica de la vigencia del imperio de las instituciones en el Estado constitucional posmoderno". Anuario de Derecho Constitucional Latinoamericano. Bogotá. Fundación Konrad Adenauer, Año XX, 763-787.

Manili, Pablo L., "La Constitución Nacional es de orden público y no admite acuerdo en contrario". La Ley 2004-D-1015.

Marrama, Silvia Estela (2018). "Análisis de un fallo sobre maternidad subrogada a la luz de la doctrina de la arbitrariedad de sentencia”. Revista República y Derecho, Volumen III. Disponible en https://repositorio.uca.edu.ar.

Marrama, Silvia (2020). Prácticas abusivas en convenios de maternidad subrogada. Buenos Aires. Erreius. Temas de Derecho de Familia, Sucesiones y Bioética.

Massimino, Leonardo (2013). "La dignidad de la persona como principio del derecho público”. Revista Rap, Año XXXV, № 418, Buenos Aires. 
Mayo, Jorge. "Persona humana y dignidad. El orden público humanista". Revista Derecho de Familia y de las Personas 2010-238.

Medina, Graciela. "Orden público en el derecho de familia”. La Ley 2015-F-742.

Mir Candal, Leila (2010). "La 'maternidad intervenida'. Reflexiones en torno a la maternidad subrogada". Revista Red Bioética. Disponible en https://redbioetica. com.ar/wp-content/uploads/2018/11/Leila.pdf.

Montero, Etienne (2015). "La maternidad de alquiler frente a la summa divisio iuris entre las personas y las cosas". Revista Persona y Derecho, No 72, 223-236.

Najurieta, María Susana (2016). "Principios y caracteres del derecho internacional privado de la infancia con especial referencia a las disposiciones del Código Civil y Comercial de la Nación". Revista Jurídica de Buenos Aires, Derecho Internacional Privado, Año 41, Nº 93, Abeledo Perrot, Facultad de Derecho - UBA.

Najurieta, María Susana. "Orden público internacional y derechos fundamentales del niño”. La Ley 1997-B-1436.

Nuño Gómez, Laura (2016). "Una nueva cláusula del Contrato Sexual: vientres de alquiler”. Isegoría. Revista de Filosofía Moral y Política N 55, 683-700. Disponible en http://isegoria.revistas.csic.es/index.php/isegoria/article/view/961.

O’Mathúna, Donal P. (2006). "La dignidad humana en la era nazi, implicaciones para la bioética contemporánea”. The Center for Bioethics \& Human Dignity, 2006, disponible en https://cbhd.org/node/2131.

Ortiz Bustos, Belisario. "Reflexiones acerca del orden público". La Ley 1981-D-834.

Oyhanarte, Julio. "El caso 'Bonfante'. La autolimitación de los jueces”. El Derecho 57-805.

Palacios, Alfredo L. (1954), La justicia social. Buenos Aires. Claridad.

Pastore, Analía G. (2018). "Maternidad subrogada: Análisis jurídico de una problemática actual". Conferencia pronunciada en el Instituto de Bioética de la Academia Nacional de Ciencias Morales y Políticas, Buenos Aires. Disponible en https://repositorio.uca.edu.ar.

Pastore, Analía G. (2019). "Adopción prenatal, Baby Hatches, Parto anónimo y Parto confidencial o discreto, ¿son alternativas jurídicamente válidas para resguardar los derechos de la madre y el niño frente a la posible legitimación del aborto?". En AA. VV. El Interés Superior del Niño. Tomo III. Asunción. Corte Suprema de Justicia de Paraguay. Instituto de Investigaciones Jurídicas. Disponible en: https://repositorio.uca.edu.ar

Perrino, Jorge Oscar; Basset, Úrsula C. [Directora de la actualización y ampliación] (2017). Derecho de Familia. Tomos II y III. $3^{\text {a }}$ edición. Buenos Aires. Abeledo Perrot.

Perugini, Alicia M.; Ramayo, Raúl A., "Constitución Nacional, derecho extranjero y orden público". La Ley 1978-D-925.

Pettigiani, Eduardo J. "La identidad de niño, ¿está solo referida a su origen? (Adopción vs. Realidad biológica)”. Jurisprudencia Argentina 1998-III-1004.

Pieper, Josef (2007). Las Virtudes fundamentales. $9^{a}$ edición. Madrid. Rialp.

Portela, Jorge G.; Maino, Carlos A. G. (2005). "Prudencia jurídica. Argumentación y razonamiento judicial”. En AA. VV. Puy Muñoz, Francisco; Portela, Jorge (Compiladores). La argumentación de los operadores jurídicos. $1^{\text {a }}$ edición. Buenos Aires. Educa, 325-376. 
Quaini, Fabiana. "La gestación por sustitución, un obstáculo cultural más que jurídico o técnico". La Ley 21-12-2020.

Rabbi-Baldi Cabanillas, Renato. "Los derechos humanos como derechos 'anteriores' o 'preexistentes': un examen a partir de la jurisprudencia de la Corte Suprema de Justicia de la Nación”. El Derecho 175-816.

Ranieri de Cechini, Débora (2013). "El neoconstitucionalismo en la reforma del Código Civil y Comercial: el protagonismo del juez en el Estado de Derecho y el problema del método de ponderación". Revista Forum, No 1, 155-219.

Ratzinger, Joseph, Benedicto XVI (2018). Liberar la libertad. Capítulo VIII, "Afirmar el derecho y combatir contra la injusticia. Discurso en el Bundestag". Alemania, del 22 de septiembre de 2011. Madrid. BAC, 141-149.

Real Academia Española (2006). Diccionario esencial de la lengua española. Madrid. Espasa Calpe.

Rubaja, Nieve. "Un nuevo caso sobre gestación por sustitución transfronteriza que llega al Tribunal Europeo de Derechos Humanos. El impacto de los lineamientos del tribunal en la jurisprudencia francesa y los interrogantes pendientes". Revista de Derecho de Familia 2021-1-217.

Sagüés, Néstor P., "La 'convención viviente' en la opinión consultiva 24/2017 de la Corte Interamericana de Derechos Humanos". La Ley 2018-C-159.

Salvat, Raymundo M. (1954), Tratado de Derecho Civil. Parte General. Tomo I. 10a edición actualizada por Víctor N. Romero del Prado. Buenos Aires. TEA.

Sambrizzi, Eduardo A. (2016). "La Filiación en el Código Civil y Comercial”. La Ley. $1^{a}$ edición. Buenos Aires.

Sambrizzi, Eduardo A., "Correcto rechazo a un reclamo de maternidad subrogada". El Derecho 22-2-2021 y 23-2-2021.

San Juan Pablo II (2014). Teología del cuerpo. Tomo I. $1^{a}$ edición. Buenos Aires. Ágape.

Santo Tomás de Aquino (1995). Suma de Teología. Parte I-II y II-II. Madrid. BAC.

Schotmans, Paul; Hansen, Bart; Veulemans, Sophie. "Un bebé como terapia. Consideraciones criticas referidas al diagnóstico preimplantatorio para la donación de células madre". Jurisprudencia Argentina 2007-IV-997.

Scotti, Luciana B., "Gestación por sustitución: acerca de la opinión consultiva del Tribunal Europeo de Derechos Humanos”. La Ley 2019-C-962.

Scotti, Luciana B. (2014). "La 'maternidad subrogada' en la legislación y jurisprudencia argentinas". Revista digital enletra.com $\mathrm{N}^{\circ} 1,47-78$.

Seoane, María Isabel (1990). Crianza y adopción en el derecho argentino precodificado, Revista de Historia del Derecho, $\mathrm{N}^{\circ}$ 18. Buenos Aires. Instituto de Investigaciones de Historia del Derecho, 355-438.

Serdán, Florencia (2021). "Nueva decisión del Tribunal Europeo de Derechos Humanos sobre maternidad subrogada”. Centro de Bioética, Persona \& Familia, disponible en https://centrodebioetica.org.

Sesin, Domingo J. (2020). “Discrecionalidad. Ponderación. Proporcionalidad”. La Ley, suplemento Constitucional No 7, 1-4.

Sodero, Eduardo; Vigo, Rodolfo L. "Orden público y orden público jurídico". La Ley 2015-F-1077. 
Spaemann, Robert (2004). Ensayos filosóficos. Artículos "Naturaleza" y "La actualidad del derecho natural". Madrid. Cristiandad, 23-45 y 67-87.

Valero Heredia, Ana (2019). "La maternidad subrogada: un asunto de derechos fundamentales". Teoría y Realidad Constitucional, No $43,421-440$.

Vigo (h), Rodolfo L. "Interpretación jurídica de los contratos civiles". La Ley 1986A-795. 